\title{
Hemiballismus Presenting as a Metabolic
}

\author{
Debipriya Saha ${ }^{1}$, Kanak Choudhury ${ }^{2}$
}

\begin{abstract}
A patient presenting with movement disorder is a cumbersome situation for the treating physicians. Here is a case of nonketotic hyperglycemia, overt hypothyroidism presenting with a sudden onset of hemiballismus with no organic lesion in the brain. Hemiballismus is a type of hyperkinetic movement disorder.

Keywords: Hemiballismus, Hyperglycemia, Metabolic complications.

Bengal Physician Journal (2019): 10.5005/jp-journals-10070-6125
\end{abstract}

\section{INTRODUCTION}

Hemiballismus is characterized by involuntary, violent, coarse, and wide amplitude movements involving ipsilateral upper and lower limbs. ${ }^{1}$ Although classically related to lesions in the subthalamic nucleus, it has been hypothesized that it may occur due to lesion outside this nucleus or may be associated with nonketotic hyperglycemia or other metabolic derangements like thyroid dysfunction, electrolyte disturbances or with complications of HIV infection as per some recent reports. ${ }^{2}$ So, treatment should be directed toward the cause, not the manifestations.

\section{Case Description}

A 60-year-old Hindu female presented to us with complaints of sudden onset of abnormal, high amplitude, intermittent movements of right upper limb for 2 days, gradually involving her right lower limb also. During those abnormal movements, she used to remain fully conscious and tried to suppress those movements by the opposite hand. It was progressive in nature, increasing in frequency day by day that she became unable to perform her daily activities by herself. She simultaneously gave a history of increased appetite for the past few days. It was not associated with the weakness of the limbs, difficulty in speech, loss of consciousness, headache, vomiting. No history of bowel and bladder involvement. She also gave history of slowness of her movement, cold intolerance for the past 4-5 years. No history of similar illness was earlier present. Not known to be diabetic or hypertensive or no history of any past illness. She is an unmarried female, who attained menopause 13 years back. On examination, she is found to be hypertensive ( $\mathrm{BP}=160 / 100 \mathrm{~mm} \mathrm{Hg}$ ), abnormal ballistic movements found involving her right upper and lower limb. Cranial nerves and motor system examinations are normal. Other system examinations are also normal. On investigations, her random blood glucose level was found to be $542 \mathrm{mg} / \mathrm{dL}$, with $\mathrm{HbA} 1 \mathrm{C}$ of $13.2 \%$, S.TSH $=150 \mu \mathrm{lU} /$ $\mathrm{mL}, \mathrm{FT} 4=1.6 \mathrm{pmol} / \mathrm{L}, \mathrm{S}$. triglyceride $=312 \mathrm{mg} / \mathrm{dL}$. Other tests like $\mathrm{CBC}$, S.electrolytes, KFT, and LFT were normal. Viral markers are negative. NCCT brain was normal. Chest X-ray was normal. MRI brain showed senile cerebral atrophy. She was started on conservative management with injection of regular insulin, oral levothyroxine, antihypertensive telmisartan, tetrabenazine, and levetiracetam to control abnormal movements. Even after 5 days of treatment, her

\begin{abstract}
1,2Department of General Medicine, Agartala Government Medical College, Agartala, Tripura, India

Corresponding Author: Kanak Choudhury, Department of Medicine, Agartala Government Medical College, Agartala, Tripura, India, Phone: +91 7085233746, e-mail: drkanakchoudhury.kc@gmail.com

How to cite this article: Saha D, Choudhury K. Hemiballismus Presenting as a Metabolic Complication. Bengal Physician Journal 2019;6(3):74-75.

Source of support: Nil

Conflict of interest: None

abnormal movements persisted, her blood sugar level gradually decreased, but still fasting blood sugar $=285 \mathrm{mg} / \mathrm{dL}$, post prandial Blood sugar $=360 \mathrm{mg} / \mathrm{dL}$. Then she was started on basal insulin along with all the previous medications. Finally, after 2 weeks of strict monitoring and meticulous treatment, her abnormal ballistic movements completely resolved, and blood sugar came under control. On follow-up, she is regularly coming to our OPD, her blood sugar level and thyroid hormone levels are well controlled with the medications.
\end{abstract}

\section{MRI BRAIN IMAGES}

Senile cerebral atrophy (Fig. 1).

\section{Discussion}

Hemiballismus is a rare hyperkinetic movement disorder. ${ }^{3}$ The acute development of hemiballismus is mostly caused by focal lesions in the contralateral basal ganglia and subthalamic nucleus. ${ }^{4}$ But this sort of acute presentation without any structural lesion in the brain is very rare. Metabolic complications like hyperglycemia and hypothyroidism need not necessarily present with chronic manifestations always, but they can give rise to such types of acute movement disorders also. Prognosis is favorable for most of the patients depending upon the underlying causes. ${ }^{5}$ So, all the neurological manifestations are not always due to neurological diseases, but some of them may be a manifestation of an underlying metabolic disorder.

o The Author(s). 2019 Open Access This article is distributed under the terms of the Creative Commons Attribution 4.0 International License (https://creativecommons. org/licenses/by-nc/4.0/), which permits unrestricted use, distribution, and non-commercial reproduction in any medium, provided you give appropriate credit to the original author(s) and the source, provide a link to the Creative Commons license, and indicate if changes were made. The Creative Commons Public Domain Dedication waiver (http://creativecommons.org/publicdomain/zero/1.0/) applies to the data made available in this article, unless otherwise stated. 


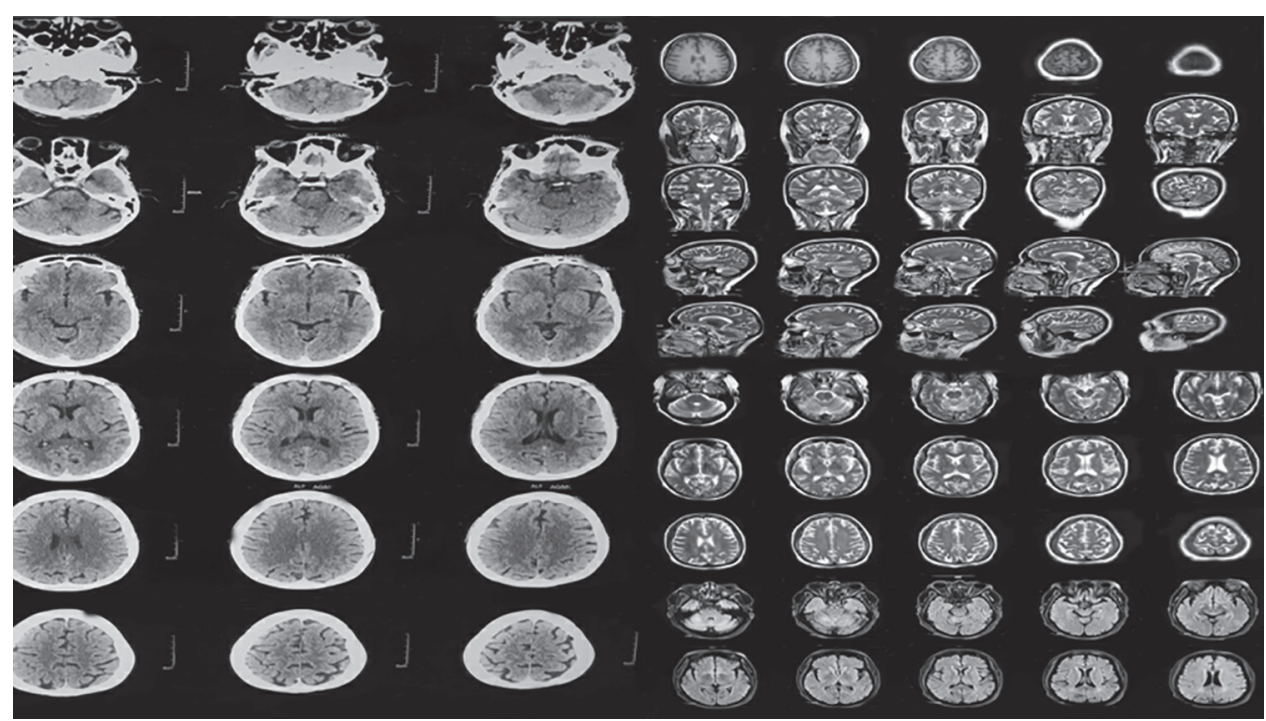

Fig. 1: MRI brain-senile cerebral atrophy only, there is no intracerebral lesion

\section{References}

1. Postuma RB, Lang AE. Hemiballism: revisiting a classic disorder. Lancet Neurol 2003;2(11):661-668. DOI: 10.1016/S1474-4422(03) 00554-4.

2. Grandas F. Hemiballismus. Handbook of Clinical Neurology 2011. vol. 100, chapter 17 pp. $249-260$.
3. Jaafar J, Rahman RA, Draman N, et al. Hemiballismus in uncontrolled diabetes mellitus. Korean J Fam Med 2018;39(3):200-203. DOI: 10.4082/kjfm.2018.39.3.200.

4. Hawley JS, Weiner WJ. Hemiballismus: current concepts and review. Parkinsonism Relat Disord 2012;18(2):125-129. DOI: 10.1016/ j.parkreldis.2011.08.015.

5. Zagrajek M, Chojdak-Łukasiewicz J, et al. Ballism as a rare form of hyperkinetic movement disorder. Wiad Lek 2013;66(2 Pt 2):171-174. 